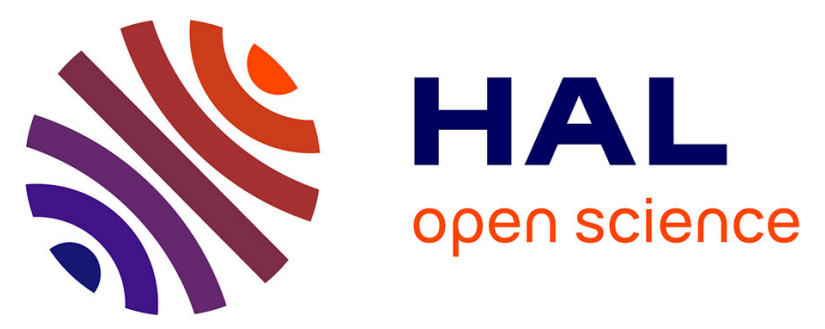

\title{
Modification of protein structures by altering the whey protein profile and heat treatment affects in vitro static digestion of model infant milk formulas
}

Amira Halabi, Thomas Croguennec, Said Bouhallab, Didier Dupont, Amélie Deglaire

\section{To cite this version:}

Amira Halabi, Thomas Croguennec, Said Bouhallab, Didier Dupont, Amélie Deglaire. Modification of protein structures by altering the whey protein profile and heat treatment affects in vitro static digestion of model infant milk formulas. Food and Function, 2020, 11, pp.6933-6945. 10.1039/d0fo01362e . hal-02911611

\section{HAL Id: hal-02911611 \\ https://hal.inrae.fr/hal-02911611}

Submitted on 4 Aug 2020

HAL is a multi-disciplinary open access archive for the deposit and dissemination of scientific research documents, whether they are published or not. The documents may come from teaching and research institutions in France or abroad, or from public or private research centers.
L'archive ouverte pluridisciplinaire HAL, est destinée au dépôt et à la diffusion de documents scientifiques de niveau recherche, publiés ou non, émanant des établissements d'enseignement et de recherche français ou étrangers, des laboratoires publics ou privés.

\section{(ㅇ)(1) $\$$}

Distributed under a Creative Commons Attribution - NonCommercial - NoDerivatives| 4.0 


\section{A) Check for updates}

Cite this: DOI: 10.1039/dOfo01362e

\section{Modification of protein structures by altering the whey protein profile and heat treatment affects in vitro static digestion of model infant milk formulas $\dagger$}

Received 26th May 2020, Accepted 16th July 2020 DOI: $10.1039 /$ dOfo01362e rsc.li/food-function

\author{
Amira Halabi, (D) Thomas Croguennec, Said Bouhallab, Didier Dupont and \\ Amélie Deglaire (D) *
}

Heat treatments induce changes in the protein structure in infant milk formulas (IMFs). The present study aims to investigate whether these structural modifications affect protein digestion. Model IMFs (1.3\% proteins), with a bovine or a human whey protein profile, were unheated or heated at $67.5^{\circ} \mathrm{C}$ or $80{ }^{\circ} \mathrm{C}$ to reach $65 \%$ of denaturation, resulting in six protein structures. IMFs were submitted to in vitro static gastrointestinal digestion simulating infant conditions. During digestion, laser light scattering was performed to analyze IMF destabilization and SDS-PAGE, OPA assay and cation exchange chromatography were used to monitor proteolysis. Results showed that, during gastric digestion, $\alpha$-lactalbumin and $\beta$-lactoglobulin were resistant to hydrolysis in a similar manner for all protein structures within IMFs $(p>0.05)$, while the heat-induced denaturation of lactoferrin significantly increased its susceptibility to hydrolysis. Casein hydrolysis was enhanced when the native casein micelle structure was modified, i.e. partially disintegrated in the presence of lactoferrin or covered by heat-denatured whey proteins. The IMF destabilization at the end of the gastric digestion varied with protein structures, with larger particle size for IMF containing native casein micelles. During intestinal digestion, the kinetics of protein hydrolysis varied with the IMF protein structures, particularly for IMFs containing denatured lactoferrin, exhibiting higher proteolysis degree $\left(67.5^{\circ} \mathrm{C}\right.$ and $80^{\circ} \mathrm{C}$ vs. unheated) and essential amino acid bioaccessibility $\left(67.5^{\circ} \mathrm{C}\right.$ vs. unheated). Overall, the protein structures, generated by modulating the whey protein profile and the heating conditions, impacted the IMF destabilization during the gastric phase and the proteolysis during the entire

simulated infant digestion.
\end{abstract}

\section{Introduction}

Human milk is specifically suited for the physiological development of infants during the first months of life thanks to its nutritional composition and bioactive compounds. When breastfeeding is not possible or not desired, infant milk formulas (IMFs) are intended to be an effective human milk substitute. Most IMFs are formulated based on skimmed bovine milk supplemented with whey proteins, originating from either cheese whey- or skimmed milk microfiltration permeate-derived whey protein isolate (WPI), lactose, vegetable oils, minerals and vitamins in amounts designed to mimic the nutritional profile of human milk. ${ }^{1,2}$ However, differences persist between human milk and IMFs, in particular regarding

STLO, INRAE, Institut Agro, 35042 Rennes, France.

E-mail: amelie.deglaire@agrocampus-ouest.fr

$\dagger$ Electronic supplementary information (ESI) available. See DOI: 10.1039/ dofo01362e the whey protein profile. While the predominant whey proteins of bovine milk are $\beta$-lactoglobulin ( $\beta$-LG) $(50 \%$ of whey proteins), $\alpha$-lactalbumin ( $\alpha$-LA) (20\% of whey proteins) and in a minor proportion lactoferrin (LF) (4\% of whey proteins), mature human milk is $\beta$-LG free and the predominant whey proteins are $\alpha$-LA ( $40 \%$ of whey proteins) and LF (25\% of whey proteins). ${ }^{3}$

Differences in whey protein profile between bovine and human milks induce some disparity in their amino acid profiles, and in particular for tryptophan and cysteine, which are essential amino acids having important roles beyond protein synthesis. $^{4,5}$ To balance this disparity in amino acid profiles, IMFs usually contain a higher protein amount than that of human milk, ${ }^{6}$ but differences in amino acid bioavailability persist as the plasma tryptophan level in infants fed with high protein-IMF remains lower than that for breastfed infants. ${ }^{7,8}$ Moreover, the high protein content in IMFs could be at the origin of overweight and obesity predispositions of infants in later life. A randomized clinical study ${ }^{9}$ revealed that infants 
aged from 2-6 years fed high-protein IMFs $\left(16 \mathrm{~g} \mathrm{~L}^{-1}\right.$ of proteins) in the first year of life had a higher fat mass than those fed low-protein IMFs (12.5 $\mathrm{g} \mathrm{L}^{-1}$ of proteins). A possible strategy to reduce the IMF protein content while respecting the amino acid requirements is to supplement IMF with bovine $\alpha$-LA or LF, which have high homology with their human counterparts $\left[72 \%{ }^{4,10}\right.$ and $69 \%{ }^{11}$ of homology, respectively], at the same levels as mature human milk. Previous clinical studies showed that lowering the IMF protein content while increasing the $\alpha$-LA content resulted in a plasma tryptophan level similar to that of breastfed newborns. ${ }^{12,13}$ Additionally, infants fed LF-supplemented IMFs developed less health diseases compared to infants fed standard IMFs, such as respiratory tract illnesses. ${ }^{14}$

It is now acknowledged that the milk protein structures can influence nutrient bioavailability, rates of absorption and postprandial outcomes. ${ }^{15-19}$ Milk protein structure can be altered by processing such as heat treatment, partly due to whey protein denaturation and aggregation. However, so far, only a few studies ${ }^{20,21}$ have directly linked these heat-induced protein structures to protein digestion kinetics, and even less in the context of IMFs.

In our previous work, the protein structures generated by varying both the whey protein profile of IMFs and the heating conditions have been characterized. ${ }^{22}$ The objective of the present paper was to investigate the impacts of these protein structures on proteolysis kinetics during simulated infant digestion. Two model IMFs were formulated at 1.3\% total proteins with a similar casein : whey protein ratio of $40: 60$ but differing by their whey protein profile. The control IMF had a similar whey protein profile to that of bovine milk, while the $\mathrm{LF}^{+} \alpha-\mathrm{LA}^{+}$IMF was formulated to contain the same $\alpha$-LA and LF amounts than those of mature human milk. The IMFs were unheated or heated at $67.5{ }^{\circ} \mathrm{C}$ or $80^{\circ} \mathrm{C}$ to reach a similar extent of whey protein denaturation (65\%). IMF destabilization during the digestion process was monitored by laser light scattering. Protein digestion kinetics were followed by determination of the proportion of residual intact milk proteins by SDS-PAGE under reducing condition, the degree of hydrolysis by OPA (o-phthalaldehyde) assay and the amino acid bioaccessibility by cation exchange chromatography.

\section{Materials and methods}

\subsection{Materials}

2.1.1. IMF ingredients. The low heat skimmed milk powder (SMP) was prepared by microfiltration of raw skimmed milk (1.4 $\mu \mathrm{m}$ cut-off) at Fromagerie Gillot (Saint-Hilaire-deBriouze, France). The microfiltered skimmed milk was concentrated in a two-stage falling film vacuum evaporator set on the first stage at $64{ }^{\circ} \mathrm{C}$. The concentrated milk temperature was $50{ }^{\circ} \mathrm{C}$ at the outlet of the first stage and $38{ }^{\circ} \mathrm{C}$ at the outlet of the evaporator. Concentrated milk was then spray-dried at the semi-industrial unit Bionov (Rennes, France) with temperatures of inlet and outlet air of $240{ }^{\circ} \mathrm{C}$ and $88^{\circ} \mathrm{C}$, respectively.
The temperature of the integrated fluid bed air was set at $75^{\circ} \mathrm{C}$. SMP was characterized by a whey protein nitrogen index of $9 \mathrm{mg}$ of nitrogen per $\mathrm{g}$ of powder. WPI (Prolacta ${ }^{\circledR 95}$ ) was purchased from Lactalis Ingredients (Bourgbarré, France). Bovine $\alpha$-LA and LF (Prodiet Lactoferrin ${ }^{\circledR}$ ) powders were kindly provided by Agropur Inc (Appleton, USA) and Ingredia Dairy Experts (Arras, France), respectively. The protein content of SMP, WPI, $\alpha$-LA and LF powders was 36\%, 88\%, 84\% and 90\% $(\mathrm{w} / \mathrm{w})$, respectively, as determined by the Kjeldahl method with a nitrogen conversion factor of 6.38. The iron saturation of the LF powder was $16 \%$ as determined by absorbance at $465 \mathrm{~nm}$. All protein powders were stored at $-20{ }^{\circ} \mathrm{C}$ until use. Lactose was supplied by Armor Proteines (Saint-Brice-en-Coglès, France). $\mathrm{CaCl}_{2} \cdot 2 \mathrm{H}_{2} \mathrm{O}$ was from AnalaR (Leuven, Belgium), $\mathrm{FeSO}_{4} \cdot 7 \mathrm{H}_{2} \mathrm{O}$ from Sigma-Aldrich (St-Louis, USA), $\mathrm{KCl}$ from Panreac (Barcelona, Spain), $\mathrm{Na}_{3} \mathrm{PO}_{4} \cdot 12 \mathrm{H}_{2} \mathrm{O}$ from Merck (Darmstadt, Germany), and $\mathrm{Na}_{3} \mathrm{C}_{6} \mathrm{H}_{5} \mathrm{O}_{7} \cdot 2 \mathrm{H}_{2} \mathrm{O}$ from Carlo Erba Reagents (Val-de-Reuil, France).

2.1.2. In vitro digestion chemicals. Pepsin was from porcine gastric mucosa (P6887; $3075 \mathrm{U} \mathrm{mg}^{-1}$ ). Pancreatin, a mix of pancreatic enzymes, was from porcine pancreas ( $\mathrm{P} 7545$; trypsin activity of $6.7 \mathrm{U} \mathrm{mg}^{-1}$; lipase activity of $85.2 \mathrm{U} \mathrm{mg}^{-1}$ ). Bile extract was from bovine bile (B3883; $0.9 \mathrm{mmol} \mathrm{g}^{-1}$ ). The enzyme activities and bile concentration were measured using the assays described in the harmonized INFOGEST protocol. ${ }^{23}$ Enzymes and bile salts, as well as enzyme inhibitors, namely Pepstatin A (P5318) and Pefabloc ${ }^{\circledR}$ SC (76307), were purchased from Sigma-Aldrich (St Quentin Fallavier, France). All other materials were of standard analytical grade.

\subsection{Preparation of the IMFs and heat treatments}

The IMFs were formulated in agreement with the European regulation (EU, 2016/127) for the bovine-milk-based IMFs regarding the contents of protein, lactose and the main minerals. The IMFs were prepared as described previously. ${ }^{22}$

IMFs were composed of $1.32 \pm 0.02 \mathrm{~g}$ of total proteins, 0.79 $\pm 0.06 \mathrm{~g}$ of whey proteins, $0.53 \pm 0.04 \mathrm{~g}$ of caseins, $5.63 \pm 0.01 \mathrm{~g}$ of lactose, $41.8 \pm 0.6 \mathrm{mg}$ of calcium, $67.1 \pm 1.9 \mathrm{mg}$ of chloride, $21.0 \pm 0.2 \mathrm{mg}$ of inorganic phosphorus, $0.4 \pm 0.0 \mathrm{mg}$ of iron, $61.3 \pm 1.6 \mathrm{mg}$ of potassium and $23.3 \pm 2.5 \mathrm{mg}$ of sodium per $100 \mathrm{~g}$ of liquid IMFs (data are means $\pm \mathrm{SD}, n=3$ ). The whey protein contents, determined by reverse-phase high performance liquid chromatography (RP-HPLC) and expressed in $\mathrm{g}$ per $100 \mathrm{~g}$ of liquid IMFs, were $0.16 \pm 0.00$ of $\alpha$-LA and $0.54 \pm 0.01$ of $\beta$-LG for the control IMF, $0.47 \pm 0.00$ of $\alpha$-LA and $0.19 \pm 0.01$ of $\mathrm{LF}$ for the $\mathrm{LF}^{+} \alpha-\mathrm{LA}^{+} \mathrm{IMF}$. The $\beta$-LG content in the $\mathrm{LF}^{+} \alpha-\mathrm{LA}^{+}$ IMF, too low to be quantified by RP-HPLC, was estimated at $0.06 \mathrm{~g}$ per $100 \mathrm{~g}$ of liquid IMF, based on the amount of $\beta$-LG in the SMP and the proportion of SMP in the IMF.

After an equilibration time of $60 \mathrm{~min}$ at $30{ }^{\circ} \mathrm{C}$, the IMFs $(20 \mathrm{~mL})$ were heat-treated at $67.5^{\circ} \mathrm{C}$ or $80^{\circ} \mathrm{C}$ as described previously. ${ }^{22}$ The holding times were fixed to achieve a total whey protein denaturation extent of $65 \%$, value within the range found in commercial IMFs. After heating, the IMF samples were cooled by immersion in ice water bath, pooled and stored at $4{ }^{\circ} \mathrm{C}$. Each heat treatment was repeated on three freshly pre- 
Table 1 Protein structure characteristics and extent of whey protein denaturation for the unheated and heated control and $\mathrm{LF}^{+} \alpha-\mathrm{LA}^{+} \mathrm{IMFs}$

\begin{tabular}{|c|c|c|c|c|c|c|}
\hline \multirow[b]{3}{*}{ IMFs } & \multirow[b]{3}{*}{ Heating conditions } & \multirow[b]{3}{*}{ Protein structures } & \multicolumn{4}{|c|}{ Extent of denaturation (\%) } \\
\hline & & & \multirow[b]{2}{*}{ Sum of whey proteins } & \multicolumn{3}{|c|}{ Individual whey proteins } \\
\hline & & & & $\alpha-\mathrm{LA}$ & $\beta$-LG & $\mathrm{LF}$ \\
\hline \multirow[t]{3}{*}{ Control } & Unheated & Native casein micelles & 0 & 0 & 0 & 0 \\
\hline & Heated at $67.5^{\circ} \mathrm{C}$ & Soluble whey protein aggregates + casein micelles & $65 \pm 2$ & $83 \pm 6$ & $59 \pm 5$ & n.d. \\
\hline & Heated at $80^{\circ} \mathrm{C}$ & Casein micelles + soluble whey protein aggregates & $63 \pm 0$ & $42 \pm 1$ & $69 \pm 0$ & n.d. \\
\hline \multirow[t]{3}{*}{$\mathrm{LF}^{+} \alpha-\mathrm{LA}^{+}$} & Unheated & Partial disintegrated casein micelles & 0 & 0 & 0 & 0 \\
\hline & Heated at $67.5^{\circ} \mathrm{C}$ & Casein micelle-bound whey protein aggregates & $64 \pm 2$ & $50 \pm 2$ & n.d. & $97 \pm 0$ \\
\hline & Heated at $80^{\circ} \mathrm{C}$ & Dense casein micelle-bound whey protein aggregates & $66 \pm 2$ & $52 \pm 3$ & n.d. & $98 \pm 0$ \\
\hline
\end{tabular}

The protein structures within IMFs were characterized in our previous study (22). Data are means \pm SD $(n=3)$. Proteins within the unheated IMFs were considered as 100\% native. The protein structures for each IMF are ordered according to their amount within the IMFs. n.d.: non determined.

pared IMFs. The extent of total whey protein denaturation of the heated IMFs at $67.5{ }^{\circ} \mathrm{C}$ or $80^{\circ} \mathrm{C}$ was $64 \pm 1 \%$, as determined by RP-HPLC.

By varying the whey protein profile of the IMFs (the control and $\mathrm{LF}^{+} \alpha-\mathrm{LA}^{+}$IMFs) and the heating conditions (unheated, heated at $67.5{ }^{\circ} \mathrm{C}$, heated at $80{ }^{\circ} \mathrm{C}$ ), six IMFs with different protein structures were generated. Their characteristics are presented in Table 1.

\subsection{In vitro gastrointestinal digestion}

In vitro gastrointestinal digestion of each IMF was carried out following a static model simulating the digestion conditions of a full-term infant at 28 days of life. ${ }^{24}$ Briefly, IMF was mixed with simulated gastric fluid (SGF), composed by $94 \mathrm{mM} \mathrm{NaCl}$ and $13 \mathrm{mM} \mathrm{KCl} \mathrm{(pH} \mathrm{6.6),} \mathrm{and} \mathrm{a} \mathrm{sufficient} \mathrm{volume} \mathrm{of} 1 \mathrm{M} \mathrm{HCl}$ to adjust the $\mathrm{pH}$ at 5.3. Freshly prepared pepsin solution in SGF (268 $\mathrm{U} \mathrm{mL}^{-1}$ of total gastric volume) was finally added. The ratio of meal to gastric secretions was 63 to $37(\mathrm{v} / \mathrm{v})$. The solution was incubated for $60 \mathrm{~min}$ at $37^{\circ} \mathrm{C}$ in a water bath under stirring at $350 \mathrm{rpm}$. The $\mathrm{pH}$ was then increased to 7 by addition of $1 \mathrm{M} \mathrm{NaOH}$ in order to stop pepsin activity before further intestinal digestion.

Simulated intestinal fluid (SIF), composed by $164 \mathrm{mM}$ $\mathrm{NaCl}, 10 \mathrm{mM} \mathrm{KCl}$ and $85 \mathrm{mM}$ sodium bicarbonate ( $\mathrm{pH} 6.6$ ), bile extract solution in SIF $\left(3.1 \mathrm{mmol} \mathrm{L}^{-1}\right.$ of total intestinal volume) and $\mathrm{CaCl}_{2}\left(1.1 \mathrm{mmol} \mathrm{L}^{-1}\right.$ of total intestinal volume) were added to the previous solution. After $\mathrm{pH}$ adjustment to 6.6 with $1 \mathrm{M} \mathrm{HCl}$, freshly prepared pancreatin solution in SIF (7.1 $\mathrm{U}$ trypsin activity per $\mathrm{mL}$ of total intestinal volume) was added. The ratio meal to gastrointestinal secretions was of 39 to $61(\mathrm{v} / \mathrm{v})$. The solution was incubated for $60 \mathrm{~min}$ at $37^{\circ} \mathrm{C}$ in a water bath under stirring at $350 \mathrm{rpm}$.

Samples were collected before digestion and during both gastric and intestinal digestions at 5, 15, 30 and $60 \mathrm{~min}$. Except for particle size distribution analysis by laser light scattering performed immediately after sampling, proteolysis was inhibited by adding $10 \mu \mathrm{L}$ of Pepstatin A $(0.73 \mathrm{mM}$ in methanol) per mL of gastric digesta or $50 \mu \mathrm{L}$ of Pefabloc $\AA$ SC $(0.1 \mathrm{M}$ in distilled water) per $\mathrm{mL}$ of intestinal digesta. Samples were stored at $-20{ }^{\circ} \mathrm{C}$ until analysis. In vitro digestion experiment was conducted on each triplicate of IMFs.

\subsection{Digesta characterization}

2.4.1. Particle size distribution. Particle size distribution of the undigested IMFs and at the end of the gastric and intestinal digestions was measured by laser light scattering using a Malvern Mastersizer 2000 (Malvern Instruments Ltd, Worcestershire, UK) with two laser sources at 633 and $466 \mathrm{~nm}$. Samples were diluted in MilliQ-water in the measurement cell to reach $3-7 \%$ of obscuration. The refractive index of protein and water were set at 1.45 and 1.33 respectively. ${ }^{25}$ Particle size measurement was performed in triplicate for each sample.

2.4.2. SDS-PAGE and intact protein quantification. SDS-PAGE was performed on undigested IMFs and on the gastric and intestinal digesta under reducing conditions using 4-12\% polyacrylamide NuPAGE Novex bis-Tris 17 -well precast gels (Novex® Life Technologies, California, USA) adapted on a Hoefer $^{\mathrm{TM}}$ miniVE vertical electrophoresis system (Pharmacia Biotech, Sweden). Samples were diluted with NuPAGE® LDS $4 \times$ sample buffer (106 mM TRIS HCl; $141 \mathrm{mM}$ TRIS base; LDS 2\%; glycerol 10\%; $0.51 \mathrm{mM}$ EDTA; $0.22 \mathrm{mM}$ SERVA® Blue G250; $0.175 \mathrm{mM}$ phenol red - $\mathrm{pH}$ 8.5) (Invitrogen, Carlsbad, CA, USA) and treated with $0.5 \mathrm{M}$ DTT. After heating at $70{ }^{\circ} \mathrm{C}$ for $10 \mathrm{~min}$, samples were loaded on gels at $5 \mu \mathrm{g}$ of proteins per well for the undigested IMF and gastric samples or $30 \mu \mathrm{g}$ of proteins per well for the intestinal samples. In order to identify the protein bands, a molecular weight marker ranging from 3.5 to 200 kDa was used (Mark 12 Unstained Standard; Novex® Life Technologies, California, USA). Pepsin or pancreatin solutions were loaded on the gels in amounts similar to those of the gastric or intestinal samples, respectively. After electrophoresis migration $(200 \mathrm{~V} ; 90 \mathrm{~min})$, the proteins were precipitated by immersing the gel in aqueous solution of $30 \%(\mathrm{v} / \mathrm{v})$ ethanol and $10 \%(\mathrm{v} / \mathrm{v})$ acetic acid for $30 \mathrm{~min}$, followed by coloration in Coomassie Biosafe (Bio-Rad Laboratories) for $120 \mathrm{~min}$. The gels were rinsed in distilled water for $90 \mathrm{~min}$ and scanned using an Image Scanner III LabScan 6.0 (GE Healthcare Europe GbmH, Velizy-Villacoublay, France). 
Bands on SDS-PAGE gels were quantified by densitometry using the software Image Quant TL ${ }^{\mathrm{TM}}$ (GE Healthcare Europe183 GbmH, Velizy-Villacoublay, France) to study the kinetics of hydrolysis of $\alpha$-LA, $\beta$-LG, LF and caseins during in vitro digestion. Intact proteins remaining in the samples were quantified following the eqn (1) after normalization of the protein peak area by the protein amount loaded in each well.

$$
\begin{aligned}
\text { Intact protein }(\%)= & \frac{\text { Protein peak area of the digested sample }}{\text { Protein peak area of the undigested IMF }} \\
& \times 100
\end{aligned}
$$

Caseins were considered as a unique band due to the poor resolution of the individual casein bands.

2.4.3. Primary amino group quantification and degree of hydrolysis. The primary amino group quantification of the undigested IMFs and of the gastric and intestinal digesta was performed using the OPA (o-phthalaldehyde) method. ${ }^{26}$ Prior to analysis, samples were centrifuged at $10000 \mathrm{~g}$ for $30 \mathrm{~min}$ at $4{ }^{\circ} \mathrm{C}$. Supernatants were diluted in distilled water, 10-times for the undigested IMF and the gastric samples or 30-times diluted for the intestinal samples, followed by a 3-times dilution in OPA reagent. Samples were then incubated at $37^{\circ} \mathrm{C}$ for $10 \mathrm{~min}$ in a flat-bottom 96-well microtiter plate (Greiner Bio-One, Courtaboeuf, France) and the absorbance was measured at $340 \mathrm{~nm}$ with a Multiskan ${ }^{\mathrm{TM}}$ GO Microplate Spectrophotometer (Thermo Fisher Scientific, Waltham, MA USA). The OPA reagent ( $\mathrm{pH} 9.5)$ was composed of SDS $(0.5 \%$ $\mathrm{w} / \mathrm{v})$, DTT (7 $\mathrm{mM})$, OPA solution in ethanol (1.9 $\mathrm{mM})$ and sodium tetraborate $(18.9 \mathrm{mM})$. Primary amino groups were quantified using a methionine standard curve in a concentration range from 0 to $2 \mathrm{mM}$. The quantification of the primary amino groups was performed in triplicate for each sample.

The degree of hydrolysis (DH) was calculated following the eqn (2), after taking into account the meal dilution by the gastrointestinal secretions. DH corresponds to the proportion of cleaved peptide bonds within IMFs.

$$
\mathrm{DH}(\%)=\frac{\mathrm{NH}_{2} \text { digested sample }-\mathrm{NH}_{2} \text { undigested IMF }}{\mathrm{NH}_{2} \text { total }-\mathrm{NH}_{2} \text { undigested IMF }} \times 100
$$

with $\mathrm{NH}_{2}$ digested sample the primary amino group content in the gastric or intestinal samples ( $\mathrm{mg} \mathrm{L}^{-1}$ of IMF), $\mathrm{NH}_{2}$ undigested IMF the primary amino group content in the undigested IMFs ( $\mathrm{mg}$ $\mathrm{L}^{-1}$ of IMF), $\mathrm{NH}_{2}$ total the total content of primary amino groups within the IMFs after acid hydrolysis by $6 \mathrm{~N} \mathrm{HCl}$ at $110^{\circ} \mathrm{C}$ for $24 \mathrm{~h}\left(\mathrm{mg} \mathrm{L}^{-1}\right.$ of IMF).

2.4.4. Amino acid quantification and amino acid bioaccessibility. The total amino acid content of each IMF was quantified as described previously. ${ }^{27}$ IMFs were chemically hydrolyzed by $6 \mathrm{~N} \mathrm{HCl}$ at $110{ }^{\circ} \mathrm{C}$ for $24 \mathrm{~h}$ and dried at $40{ }^{\circ} \mathrm{C}$ under vacuum. Samples were re-dispersed in distilled water, filtered at $0.45 \mu \mathrm{m}$ and diluted 3-times with $0.2 \mathrm{M}$ lithium citrate buffer $(\mathrm{pH} 2.2)$. Samples $(50 \mu \mathrm{L})$ were then injected in the cation exchange column of Biochrom 30 automatic AA analyzer (Biochrom Ltd, Cambridge, UK) with post-column derivatization with ninhydrin (EZ Nin Reagent ${ }^{\mathrm{TM}}$, Biochrom Ltd, Cambridge, UK) as described previously. ${ }^{28}$ The ninhydrin derivative of proline was detected at $440 \mathrm{~nm}$ and the derivatives of other amino acids were detected at $570 \mathrm{~nm}$. Lithium citrate buffers were used as eluents. Methionine and cysteine were determined separately after overnight cold performic acid oxidation followed by acid hydrolysis and were quantified as methionine sulfone and cysteic acid, respectively. The quantification of the total AAs of IMFs was performed for at least two independent freshly prepared IMFs. The amino acid composition of the control and $\mathrm{LF}^{+} \alpha-\mathrm{LA}^{+}$IMFs is presented on Table 2. Tryptophan amount of the IMFs was not determined due to oxidative degradation during acid hydrolysis, but it was estimated based on the amount of $\alpha$-LA, $\beta$-LG and LF in the control and $\mathrm{LF}^{+} \alpha-\mathrm{LA}^{+}$IMFs and the tryptophan amount for each protein. ${ }^{29,30}$

The free amino acids at the end of the in vitro digestion were determined after deproteinization by sulfosalicylic acid. ${ }^{31}$ Samples were mixed with sulfosalicylic acid solution $(0.5 \mathrm{~g}$ $\mathrm{mL}^{-1}$ ) and incubated for $60 \mathrm{~min}$ at $4{ }^{\circ} \mathrm{C}$. The mixtures were centrifuged at $5000 \mathrm{~g}$ for $15 \mathrm{~min}$ at $4{ }^{\circ} \mathrm{C}$ and the supernatants were filtered at $0.45 \mu \mathrm{m}$. The filtrate was diluted 4-times with $0.2 \mathrm{M}$ lithium citrate buffer $(\mathrm{pH} 2.2)$ before injection $(50 \mu \mathrm{L})$. The amino acid analysis was performed as described above.

The amino acid bioaccessibility was calculated following the eqn (3).

$$
\begin{aligned}
& \text { Amino acid bioaccessibility }(\%) \\
& =\frac{\text { Free amino acids } s_{\text {digested sample }}}{\text { Total amino acids }} \times 100
\end{aligned}
$$

Table 2 Total amino acid composition of the control and $\mathrm{LF}^{+} \alpha-\mathrm{LA}^{+}$ IMFs

\begin{tabular}{lll}
\hline Amino acids $\left(\mathrm{g} \mathrm{kg}^{-1}\right.$ of IMF $)$ & Control IMF & $\mathrm{LF}^{+} \alpha-\mathrm{LA}^{+} \mathrm{IMF}$ \\
\hline Cys & $0.32 \pm 0.00$ & $0.41 \pm 0.01$ \\
His & $0.32 \pm 0.01$ & $0.32 \pm 0.01$ \\
Ile & $0.76 \pm 0.01$ & $0.65 \pm 0.01$ \\
Leu & $1.56 \pm 0.03$ & $1.35 \pm 0.01$ \\
Lys & $1.33 \pm 0.01$ & $1.25 \pm 0.01$ \\
Met & $0.42 \pm 0.00$ & $0.30 \pm 0.01$ \\
Phe & $0.58 \pm 0.02$ & $0.64 \pm 0.01$ \\
Thr & $0.79 \pm 0.01$ & $0.70 \pm 0.02$ \\
Trp & 0.19 & 0.30 \\
Tyr & $0.55 \pm 0.00$ & $0.61 \pm 0.03$ \\
Val & $0.79 \pm 0.02$ & $0.72 \pm 0.00$ \\
Ala & $0.58 \pm 0.01$ & $0.48 \pm 0.00$ \\
Arg & $0.36 \pm 0.02$ & $0.44 \pm 0.01$ \\
Asp + Asn & $1.38 \pm 0.01$ & $1.50 \pm 0.02$ \\
Glu + Gln & $2.78 \pm 0.01$ & $2.32 \pm 0.04$ \\
Gly & $0.27 \pm 0.01$ & $0.35 \pm 0.00$ \\
Pro & $0.95 \pm 0.02$ & $0.82 \pm 0.01$ \\
Ser & $0.68 \pm 0.02$ & $0.64 \pm 0.01$ \\
Total nitrogen & $1.96 \pm 0.01$ & $1.89 \pm 0.08$
\end{tabular}

${ }^{a}$ The tryptophan amount of the IMFs was estimated based on the amount of $\alpha$-LA, $\beta$-LG and LF in the control and $\mathrm{LF}^{+} \alpha-\mathrm{LA}^{+}$IMFs and the tryptophan amount for each protein $(29,30)$. Data are means \pm SD ( $n=2$ for the control IMF and $n=3$ for the $\mathrm{LF}^{+} \alpha-\mathrm{LA}^{+} \mathrm{IMF}$ ). 


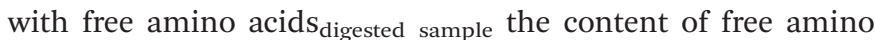
acids at the end of the in vitro digestion $\left(\mathrm{g} \mathrm{kg}^{-1}\right.$ of IMF) and total amino acids $s_{\text {undigested IMF }}$ the content of total amino acids within IMFs ( $\mathrm{g} \mathrm{kg}^{-1}$ of IMF).

\subsection{Statistical analysis}

All data are reported as means \pm standard deviation (SD). Data statistical analysis was performed using the $\mathrm{R}$ software (version 3.6.1).

Residual intact protein and $\mathrm{DH}$ variables were analyzed within the gastric or intestinal phase using a mixed linear model for repeated measures (nlme package) with "time" (4 levels: 5 min $-15 \min -30 \mathrm{~min}-60 \mathrm{~min}$ ), "formula" (2 levels: control IMF $\left.-\mathrm{LF}^{+} \alpha-\mathrm{LA}^{+} \mathrm{IMF}\right)$ and "treatment" nested within "formula" (3 levels: unheated - heated at $67.5{ }^{\circ} \mathrm{C}$ - heated at $80{ }^{\circ} \mathrm{C}$ ) as fixed factors, and digestion replicates as random factor. Residual normality and variance homogeneity for each factor were tested for all variable with Shapiro-Wilk test and Levene test, respectively (lawstat package). When data did not conform to the previous conditions, BoxCox-transformation was performed (MASS package). The residual intact casein variable was $\log 10$-transformed and the $\mathrm{DH}$ variable was square root-transformed. Amino acid bioaccessibility variable was investigated using a linear model with "formula" and "treatment" nested within "formula" as fixed factors. When differences were significant $(p<0.05)$, pairwise multiple comparison of the means was carried out using Tukey's test (lsmeans package).

\section{Results and discussion}

\subsection{Particle size distribution}

Fig. 1 shows the particle size distributions of the unheated and heated control and $\mathrm{LF}^{+} \alpha-\mathrm{LA}^{+}$IMFs. At this scale of observation, the particle size distributions of the undigested IMFs were similar with an almost unimodal distribution (Fig. 1A). The main peak with an average mode of $0.14 \mu \mathrm{m}$ was assigned to the casein micelles as this peak was significantly reduced in the presence of ethylenediaminetetraacetic acid (EDTA), a calcium-chelator which induced casein micelle dissociation. ${ }^{32}$ A wide peak of small intensity in the region of $10-100 \mu \mathrm{m}$, probably corresponding to heat-induced protein entities formed by heating and/or insoluble particles resulting from IMF preparation, was also observed.

3.1.1. At the end of the gastric digestion. After $60 \mathrm{~min}$ of gastric digestion, the particle size of the digesta was increased for the control and $\mathrm{LF}^{+} \alpha-\mathrm{LA}^{+}$IMFs compared to the corresponding undigested IMFs (Fig. 1B), but in a different manner depending on the IMF (whey protein profile and/or heating temperature). This difference in size was confirmed by confocal microscopy analysis (ESI Fig. $1 \dagger$ ).

3.1.1.1. The unheated control IMF. The particle size for the unheated control IMF (mode of $82.4 \pm 0.7 \mu \mathrm{m}$ ) was larger than that for the heated control IMFs (mode of $10.3 \pm 1.7 \mu \mathrm{m}$ ). This was in accordance with the previous observations of a larger casein coagulum size of raw skimmed bovine milk compared to that of heated skimmed milk during gastric digestion. ${ }^{33}$ The large increase of particle size at the end of the gastric digestion for the unheated control IMF was a consequence of the pepsin action and not of the acidification, as demonstrated after $\mathrm{pH}$ adjustment of the undigested IMF at 5.3 without pepsin (Fig. 1B.I). This was expected as the gastric $\mathrm{pH}$ (pH 5.3) was superior to the $\mathrm{pH}$ at which the aggregation of native casein micelles occurs ( $\mathrm{pH}$ 4.9). ${ }^{34}$ The casein micelles of the unheated control IMF were in a spherical form with $\kappa$-caseins covering its surface at $\mathrm{pH}$ between 6.7 and 5.2. ${ }^{35}$ Pepsin action on $\kappa$-caseins must have conducted to the destabilization of the casein micelles and to the formation of large particles at $\mathrm{pH}$ 5.3. ${ }^{36}$

3.1.1.2. The unheated $L F^{+} \alpha-L A^{+} I M F$. Contrary to the control IMFs, the particle size for the unheated $\mathrm{LF}^{+} \alpha-\mathrm{LA}^{+}$IMF (mode of $1.2 \pm 0.4 \mu \mathrm{m})$ was lower than that for the heated $\mathrm{LF}^{+} \alpha-\mathrm{LA}^{+}$ IMFs (mode of $11.1 \pm 2.4 \mu \mathrm{m}$ ). Opposite observations were made by De Oliveira et $a{ }^{37}$ on human milk, having a protein profile close to that of the $\mathrm{LF}^{+} \alpha-\mathrm{LA}^{+} \mathrm{IMF}$, where the particle size during dynamic in vitro gastric digestion was larger for raw human milk than for pasteurized human milk at $\sim \mathrm{pH}$ 5.4. The apparent contrast between our results and the conclusions of De Oliveira et al. ${ }^{37}$ may be explained by the different composition and/or structure between the $\mathrm{LF}^{+} \alpha-\mathrm{LA}^{+} \mathrm{IMF}$ and human milk and the different in vitro digestion conditions. For the unheated $\mathrm{LF}^{+} \alpha-\mathrm{LA}^{+} \mathrm{IMF}$, the particle size at $60 \mathrm{~min}$ of gastric digestion was moderately increased, presenting a bimodal distribution with a major peak centered at $1.2 \pm 0.4 \mu \mathrm{m}$ and a minor peak at $0.15 \pm 0.03 \mu \mathrm{m}$ (Fig. 1B.II). Similar size increase was also observed for the undigested IMF at $\mathrm{pH} 5.3$ without pepsin. Before digestion of the unheated $\mathrm{LF}^{+} \alpha-\mathrm{LA}^{+} \mathrm{IMF}$, LF binding to casein micelles partially disintegrated the latter, leading to open casein micelle structure (Table 1). ${ }^{22,38}$ The acidification of $\mathrm{LF}^{+} \alpha-\mathrm{LA}^{+} \mathrm{IMF}$ at $\mathrm{pH} 5.3$ induced a reduction of the electrostatic interactions between LF and the casein micelles, due to the decrease of casein micelle net charge. ${ }^{39}$ In the same time, the partially disintegrated casein micelles seemed to be able to interact in the form of small particles (mainly lower than $10 \mu \mathrm{m}$ ). Such entities were not observed with the native casein micelles.

3.1.1.3. The heated IMFs. All the heated IMFs presented a near similar particle size distribution at the end of the gastric digestion, independently of the heating temperature $\left(67.5^{\circ} \mathrm{C}\right.$ or $80^{\circ} \mathrm{C}$ ) or of the whey protein profile of IMFs (Fig. 1B). The particle size increase at the end of the gastric digestion of the heated IMFs compared to that for the undigested IMFs was due to the acid coagulation of whey protein-coated casein micelles as similar size increase was also observed for the undigested heated IMF at pH 5.3 without pepsin. This increase in particle size at pH 5.3 was in agreement with the observations made on heated bovine milk. ${ }^{34,40}$

3.1.2. At the end of the intestinal digestion. After $60 \mathrm{~min}$ of intestinal digestion (Fig. 1C), the bimodal particle size distributions for all IMFs were alike. The wide peak between 1 and $1000 \mu \mathrm{m}$ was assigned to pancreatin contained in the 

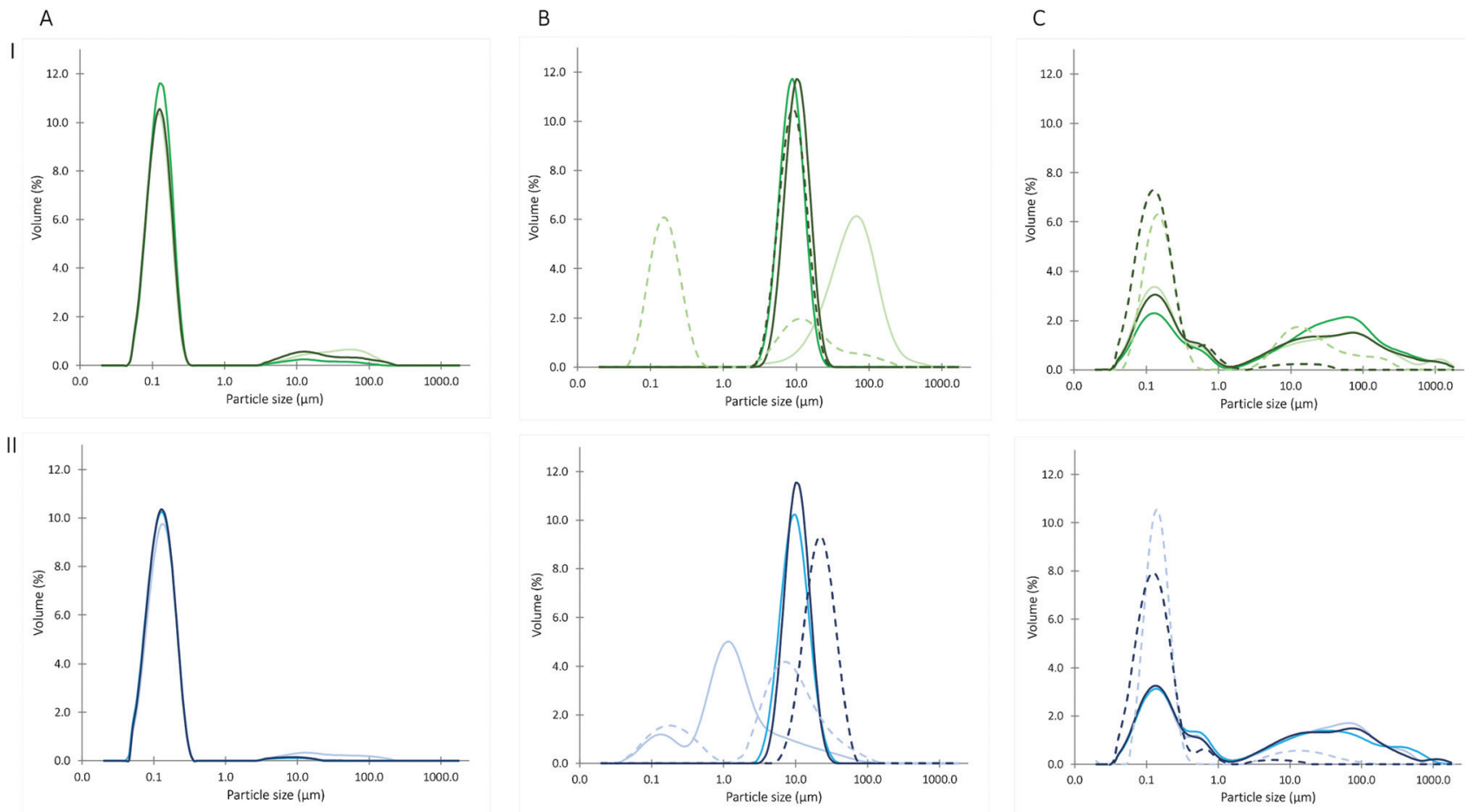

$$
\begin{array}{lll}
\text { - Control / Unheated } & - \text { Control / Heated at } 67.5^{\circ} \mathrm{C} & - \text { Control } / \text { Heated at } 80^{\circ} \mathrm{C} \\
-\mathrm{LF}^{+} \alpha-\mathrm{LA}^{+} / \text {Unheated } & -\mathrm{LF}^{+} \alpha-\mathrm{LA}^{+} / \text {Heated at } 67.5^{\circ} \mathrm{C} & -\mathrm{LF}^{+} \alpha-\mathrm{LA}^{+} / \text {Heated at } 80^{\circ} \mathrm{C}
\end{array}
$$

Fig. 1 Particle size distributions of the unheated and heated control (I) and $\mathrm{LF}^{+} \alpha-\mathrm{LA}^{+}$(II) IMFs before digestion (A) and at the end of the in vitro gastric (B) and intestinal (C) digestions, as determined by laser light scattering. The pH of the IMFs was 6.8 before digestion, 5.3 at the end of the gastric digestion and 6.6 at the end of the intestinal digestion. The dotted lines correspond to the particle size distribution of the IMFs after pH adjustment at 5.3 or 6.6 in absence of digestive enzymes. Data represent means of three independent digestion experiments $(n=3)$, with each measurement performed in triplicate.

intestinal digesta (ESI Fig. 2†). The global decrease of particle sizes (with an approximately mode of $0.1 \mu \mathrm{m}$ ) compared to those at the end of gastric digestion was due to protein hydrolysis by intestinal enzymes and/or to residual protein structures within undigested IMFs.

\subsection{Protein hydrolysis kinetics}

Proteolysis kinetics of caseins, $\alpha-\mathrm{LA}, \beta$-LG and LF, as quantified from SDS-PAGE analysis under reducing conditions (Fig. 2), are presented in Fig. 3.

During the gastrointestinal digestion of the unheated control IMF and the heated control IMF at $67.5^{\circ} \mathrm{C}$, bovine serum albumin (BSA) resisted to enzymatic hydrolysis, as observed previously during gastric digestion of human milk ${ }^{41}$ or IMFs. ${ }^{42}$ However, it was progressively hydrolyzed during the gastric digestion of the heated control IMF at $80{ }^{\circ} \mathrm{C}$ until total band disappearance at $60 \mathrm{~min}$ of gastric digestion. This could be explained by different conformation of BSA in IMF heated at $80{ }^{\circ} \mathrm{C} v s$. in unheated IMF or IMF heated at $67.5{ }^{\circ} \mathrm{C}$. The heat-denaturation of BSA in IMF heated at $80^{\circ} \mathrm{C}$ enhanced its susceptibility to pepsin hydrolysis. BSA content in IMFs was too low to be quantified.
3.2.1. Caseins. During the gastric digestion, the kinetics of casein hydrolysis were slower for the unheated control IMF than for the other IMFs (Fig. 3A), particularly at $30 \mathrm{~min}$ of gastric digestion where it reached statistical significance with $17 \pm 4 \%$ vs. $6 \pm 1 \%$ of residual intact caseins for the unheated control IMF $v s$. the other IMFs, respectively. The resistance of the native casein micelles (unheated control IMF) to pepsin hydrolysis could be explained by the larger size of particles formed during gastric digestion compared to those formed from the dissociated casein micelles by LF (unheated $\mathrm{LF}^{+}$ $\alpha-\mathrm{LA}^{+} \mathrm{IMF}$ ) or the casein micelles bound to denatured whey proteins (heated IMFs) (Fig. 1B), thus limiting the pepsin access to cleavage sites. Concomitantly to the casein hydrolysis, bands ranging from 3.5 to $6 \mathrm{kDa}$, assigned to products of casein proteolysis amongst other, such as reported previously, ${ }^{24}$ were less intense for the unheated IMFs compared to the heated IMFs (Fig. 2A).

3.2.2. $\alpha$-LA and $\beta$-LG. The SDS-PAGE analysis of the control and $\mathrm{LF}^{+} \alpha-\mathrm{LA}^{+}$IMFs (Fig. 2A) showed a resistance to pepsin hydrolysis for $\beta$-LG and $\alpha$-LA. $\beta$-LG was totally resistant to pepsin hydrolysis over the gastric digestion with no significant difference between the unheated and heated control IMFs (Fig. 3B). $\alpha$-LA was hydrolyzed during gastric digestion in a 
A
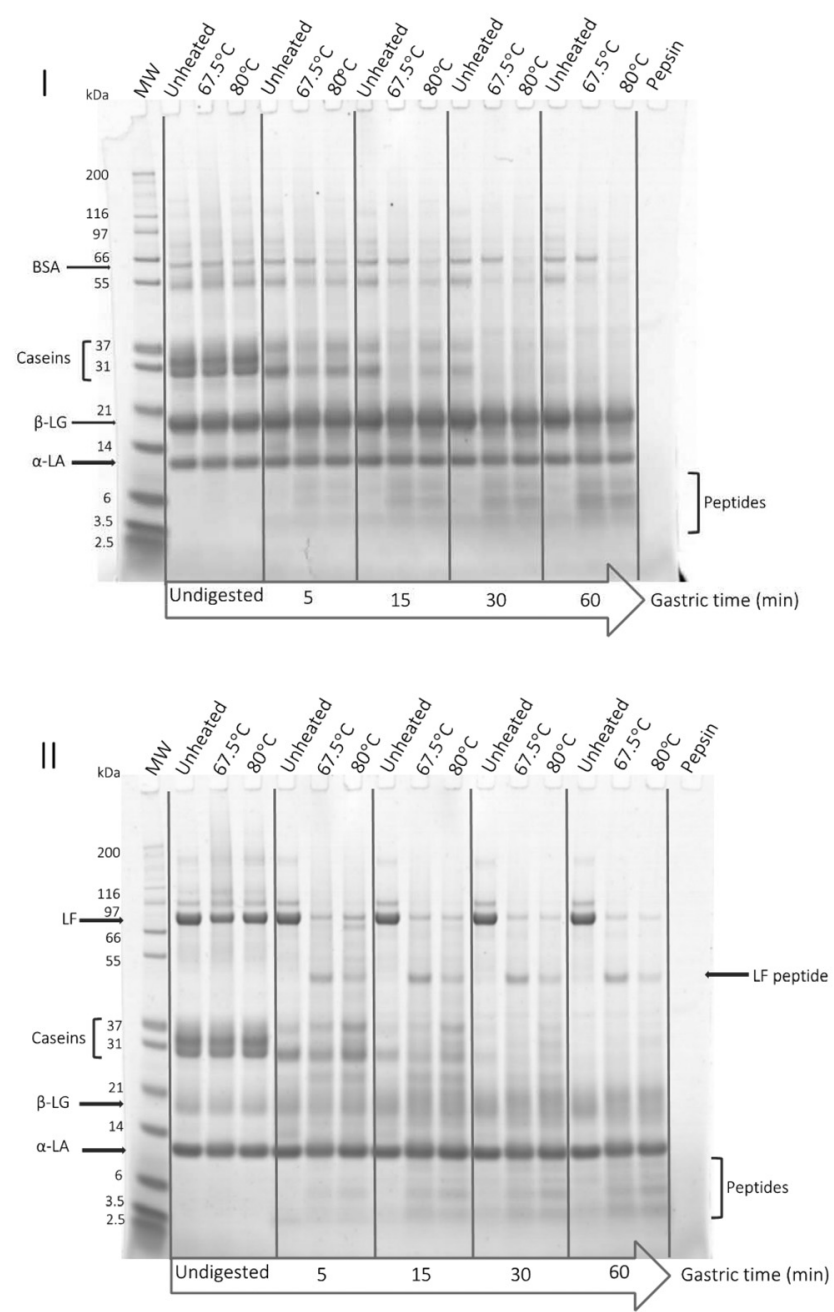

B
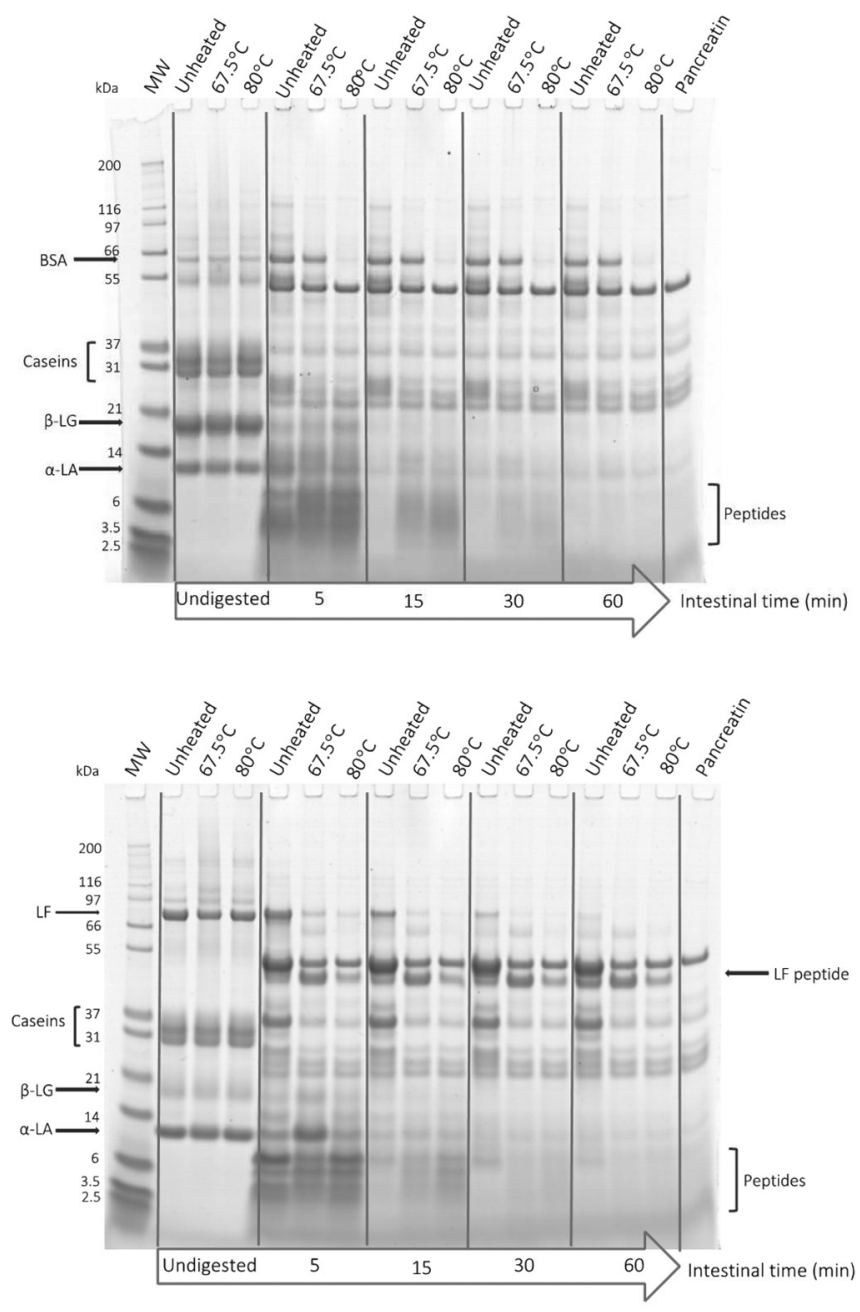

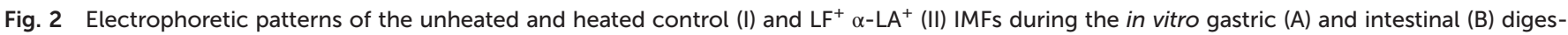

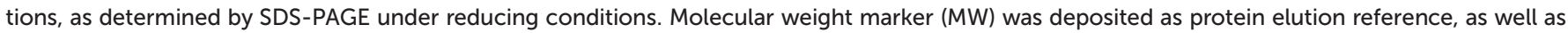

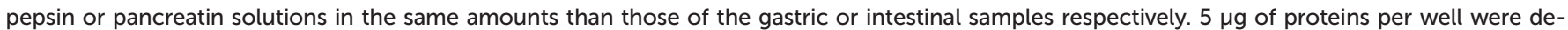

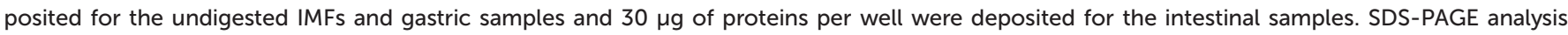
was realized once for each in vitro digestion experiments $(n=3)$.

similar manner for all IMFs $(p>0.05)$, down to $71 \pm 10 \%$ of residual intact $\alpha$-LA at $60 \mathrm{~min}$ (Fig. 3C).

The similar kinetics of $\beta$-LG or $\alpha$-LA hydrolysis between the unheated and heated IMFs were in agreement with a previous study investigating the pasteurization effects on in vitro digestion of IMFs, where, in addition, a lower pepsin resistance of $\alpha$-LA compared to that of $\beta$-LG was observed. ${ }^{43}$ However, other authors have reported an enhancement of whey protein hydrolysis with heat treatment due to whey protein unfolding and thus an increased accessibility of protein cleavage sites, ${ }^{17,25,44}$ or at the opposite a slowing down of their hydrolysis ${ }^{45}$ during gastric digestion. The apparent discrepancy among studies are likely due to different heat-induced protein structures that can vary depending on the heating parameters, such as reported by Peram et $a .^{46}$ In the present study, denatured $\alpha$-LA and $\beta$-LG within the heated IMFs were bound on the casein micelle surface and/or formed soluble aggregates (Table 1). The similar $\beta$-LG or $\alpha$-LA gastric hydrolysis between the unheated and heated IMFs could be explained by the limited access of pepsin cleavage sites on the heat-induced protein structures due to steric hindrance. ${ }^{47}$ In addition, the disulfide interactions involved in the heat-induced protein structures within the heated $\mathrm{IMFs}^{22}$ could limit the pepsin hydrolysis, contrary to the non-covalent interactions. ${ }^{21}$ Regarding the intestinal digestion, $\beta$-LG and $\alpha$-LA were rapidly hydrolyzed during the first minutes as no intact protein was detected after $5 \mathrm{~min}$ of digestion (Fig. 2B).

3.2.3. LF. The band intensity of the $L F$ for the unheated and heated $\mathrm{LF}^{+} \alpha-\mathrm{LA}^{+}$IMFs was similar before digestion (Fig. 2A.II), while 98\% of LF was in non-native form for the heated IMFs (Table 1). This was in accordance with our previous study showing that LF formed, with $\alpha$-LA and caseins, 

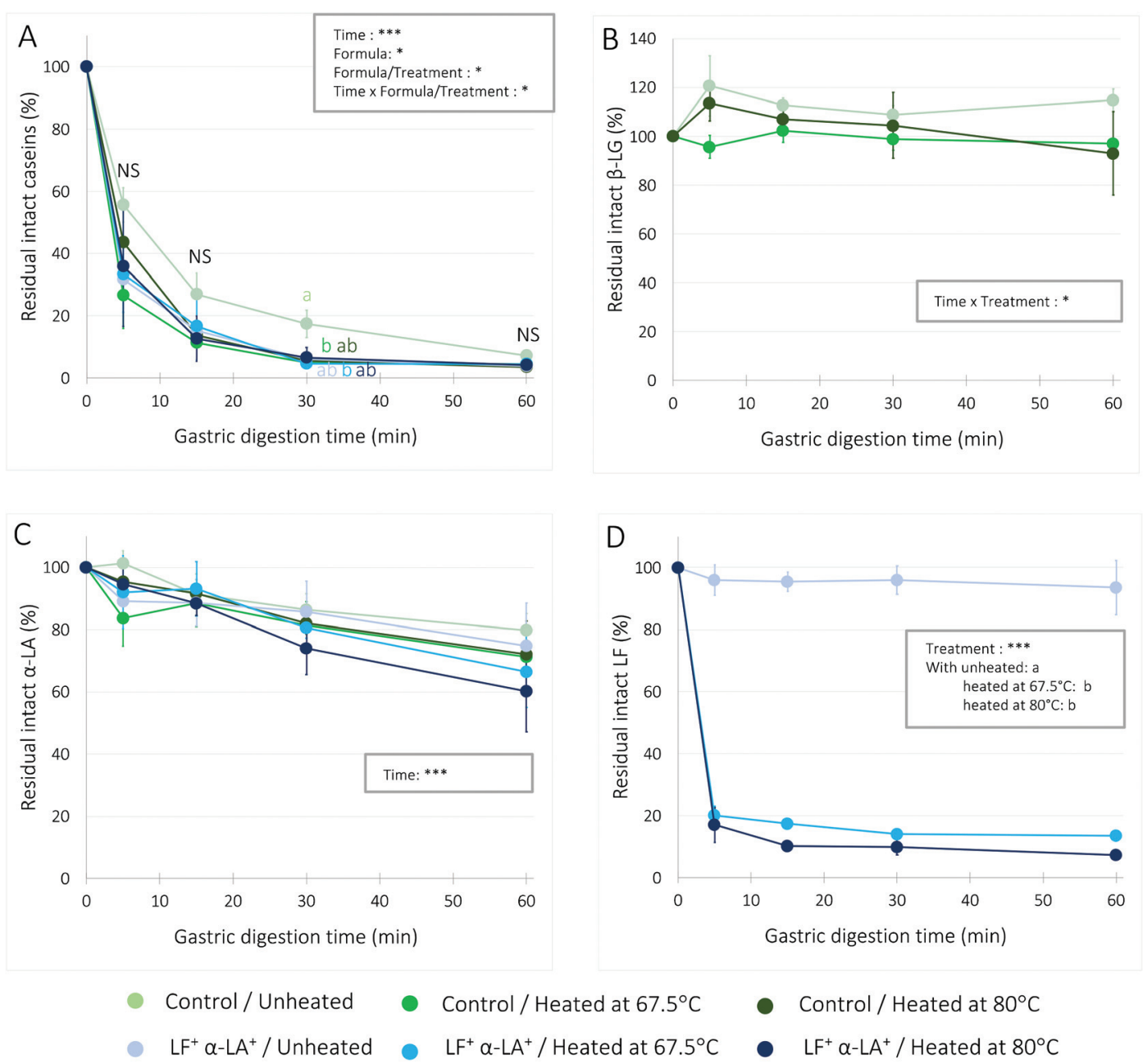

Fig. 3 Proportions of residual intact caseins (A), $\beta$-lactoglobulin (B), $\alpha$-lactalbumin (C), and lactoferrin (D) during the in vitro gastric digestion of the unheated and heated control and $\mathrm{LF}^{+} \alpha-\mathrm{LA}^{+} \mathrm{IMFs}$, as determined by densitometric analysis of SDS-PAGE patterns. Data are means \pm SD ( $n=3$ ). Statistically significant factors were referenced with $p<0.001\left(^{(* *)}, p<0.01{ }^{(* *}\right), p<0.05\left(^{*}\right)$ and $p>0.05$ (NS). Different superscript letters for a given digestion time represent significant difference among treatments nested within formulas $(p<0.05)$. Data from undigested IMFs were not included in the statistical analysis. Data for residual intact caseins were log-transformed to respect residual normality and variance homogeneity (BoxCox transformation).

heat-induced aggregates linked by disulfide interactions, which were thus reversible after reducing SDS-PAGE. ${ }^{22}$

The kinetics of LF hydrolysis during gastric digestion (Fig. 3D) showed that LF in its native form (unheated $\mathrm{LF}^{+} \alpha-\mathrm{LA}^{+}$ IMF) was resistant to pepsin hydrolysis with $94 \pm 9 \%$ of residual intact $\mathrm{LF}$ at $60 \mathrm{~min}$. The resistance of native $\mathrm{LF}$ to pepsin hydrolysis was explained by its globular structure. ${ }^{48}$ On the contrary, its hydrolysis was drastically enhanced for the denatured form (heated $\mathrm{LF}^{+} \alpha-\mathrm{LA}^{+}$IMFs) since the very first minutes of digestion, with only $19 \pm 4 \%$ of residual intact LF remaining at $5 \mathrm{~min}$ of gastric digestion. The same increase of LF hydrolysis was noticed after holder pasteurization of human milk. ${ }^{37}$ It was supposed that the heat-induced LF denaturation led to better accessibility of hidden pepsin cleavage sites. ${ }^{49}$ The LF hydrolysis by pepsin during the gastric digestion of the heated $\mathrm{LF}^{+} \alpha-\mathrm{LA}^{+}$IMFs generated a peptide of $\sim 50 \mathrm{kDa}$ (Fig. 2A.II), such as previously observed during the in vitro infant gastric digestion of LF solution. ${ }^{50}$ This $50 \mathrm{kDa}$ peptide, identified as the C-terminal fragment of the protein, ${ }^{51}$ was resistant to pepsin hydrolysis as its band intensity was unchanged during the gastric digestion.

Regarding the intestinal digestion, and as observed for $\beta$-LG and $\alpha$-LA, the LF hydrolysis occurred since the first minutes of digestion of the unheated $\mathrm{LF}^{+} \alpha-\mathrm{LA}^{+} \mathrm{IMF}$, with a total LF band disappearance at $60 \mathrm{~min}$ of intestinal digestion (Fig. 2B.II). Concomitantly to LF hydrolysis, an electrophoretic band corresponding to the C-terminal fragment of LF was observed in the early stages of intestinal digestion of the unheated $\mathrm{LF}^{+} \alpha-\mathrm{LA}^{+}$IMF. The C-terminal fragment of LF was resistant to intestinal hydrolysis for all IMFs, such as previously reported. ${ }^{52}$ In addition to the $50 \mathrm{kDa}$ electrophoretic band, another band at $\sim 37 \mathrm{kDa}$ was observed from $5 \mathrm{~min}$ of intestinal digestion for the unheated and heated $\mathrm{LF}^{+} \alpha-\mathrm{LA}^{+}$ IMFs, with a higher intensity for the unheated IMF. This poly- 
peptide, resistant to intestinal digestion, was attributed to a product of LF hydrolysis by intestinal enzymes.

The resistance of the C-terminal fragment of LF to hydrolysis throughout the gastrointestinal digestion for the unheated and heated $\mathrm{LF}^{+} \alpha-\mathrm{LA}^{+}$IMFs could have nutritional benefits for infants as this peptide has been reported to keep some bioactive properties of native LF such as the ability to bind one iron ion, ${ }^{51,52}$ the antimicrobial and antifungal activities. ${ }^{53}$ However, it does not cover the diverse range of physiological functions of native LF, such as the cell growth promoting and differentiation activities or the anti-inflammatory properties. ${ }^{54}$ Previous works showed that the osteogenic activity of $\mathrm{LF}^{55}$ and the antibacterial activity of LF on Cronobacter sakaza$k i i^{56}$ were decreased when the heat treatment intensity increased. Overall, the physiological impact of the unheated vs. heated $\mathrm{LF}^{+} \alpha-\mathrm{LA}^{+}$IMFs remains to be evaluated in vivo.

\subsection{Degree of hydrolysis and amino acid bioaccessibility}

Fig. 4 shows the evolution of $\mathrm{DH}$ during the in vitro intestinal digestion of the IMFs. Regarding the gastric digestion, the hydrolysis was very limited for all IMFs with a DH of $2 \pm 1 \%$ at 60 min (data not shown). This low DH value was due to the large peptides formed during gastric digestion of IMFs, as observed at $60 \mathrm{~min}$ of gastric digestion by SDS-PAGE analysis (Fig. 2A). For all IMFs, DH increased sharply in the first $5 \mathrm{~min}$ of the intestinal digestion but to a different extent depending on the IMF, with a DH reaching $14 \pm 2 \%$ (heated control IMFs), $24 \pm 2 \%$ (unheated IMFs) or $44 \pm 1 \%$ (heated $\mathrm{LF}^{+} \alpha-\mathrm{LA}^{+}$ IMFs). From $5 \mathrm{~min}$ to $60 \mathrm{~min}$ of intestinal digestion, the $\mathrm{DH}$ increase slowed down, but again with a kinetics depending on the IMF. The DH increase was only of 1.5-times for the unheated IMFs and the heated $\mathrm{LF}^{+} \alpha-\mathrm{LA}^{+}$IMFs, and of more than 2-times for the heated control IMFs.

Within the control IMFs, the only significant difference between the unheated and heated IMFs were found in the early phase of intestinal digestion ( $5 \mathrm{~min}$ ), with a lower $\mathrm{DH}$ for the heated control IMFs $(14 \pm 2 \%)$ compared to the unheated control IMF $(24 \pm 2 \%)$. Similar kinetics of proteolysis was observed after 15 min of intestinal digestion for the unheated and heated control IMFs, which reached a final DH of $35 \pm$ $2 \%$, value in accordance with Le Roux et al. ${ }^{57}$ who reported a $\mathrm{DH}$ of $\sim 40 \%$ at $60 \mathrm{~min}$ of in vitro static intestinal digestion of bovine milk-based IMF.

During the whole intestinal digestion period, $\mathrm{DH}$ values were significantly higher for the heated $\mathrm{LF}^{+} \alpha-\mathrm{LA}^{+}$IMFs compared to all the other IMFs $(p<0.001)$. The final DH reached $61 \pm 1 \%$ for the heated $\mathrm{LF}^{+} \alpha-\mathrm{LA}^{+}$IMFs $v s .40 \pm 1 \%$ for the unheated $\mathrm{LF}^{+} \alpha-\mathrm{LA}^{+} \mathrm{IMF}$, which was a consequence of the greater extent of LF hydrolysis during the gastric digestion for the denatured LF compared to the native LF (Fig. 3D). These final DH were significantly higher than that for the unheated control IMF, which reached a value of $32 \pm 1 \%$. The different kinetics of proteolysis among the heated $\mathrm{LF}^{+} \alpha-\mathrm{LA}^{+}$or control IMFs and unheated IMFs is likely to impact the in vivo kinetics of amino acid absorption, which in turn could modulate the

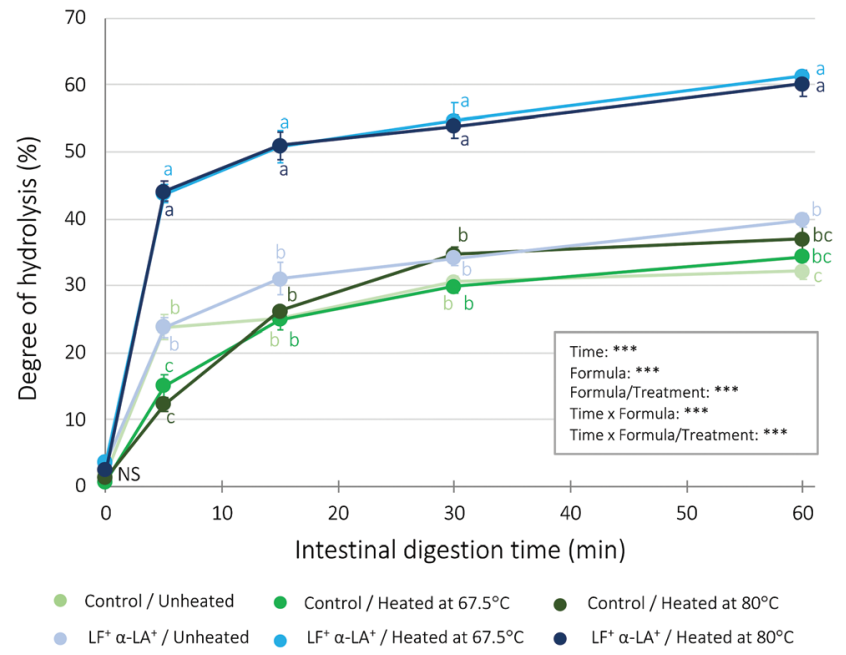

Fig. 4 Evolution of the degree of hydrolysis during the in vitro intestinal digestion of the unheated and heated control and $\mathrm{LF}^{+} \alpha-\mathrm{LA}^{+} \mathrm{IMFs}$, as determined by OPA method. Data are means \pm SD $(n=3)$, with each measurement performed in triplicate. Statistically significant factors

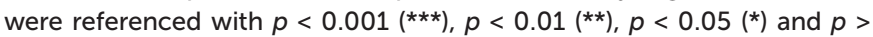
0.05 (NS). Different superscript letters for a given digestion time represent significant difference among treatments nested within formulas $(p<0.05)$. Data at time 0 min correspond to those obtained at $60 \mathrm{~min}$ of the gastric digestion. Data were square root-transformed to respect residual normality and variance homogeneity (BoxCox transformation).

postprandial regional metabolism of nitrogen, at least as demonstrated in adult. ${ }^{58}$

Fig. 5 shows the bioaccessibility of essential and non-essential amino acids at the end of in vitro digestion of the unheated and heated control and $\mathrm{LF}^{+} \alpha-\mathrm{LA}^{+}$IMFs. At $60 \mathrm{~min}$ of intestinal digestion, similar bioaccessibility of $\alpha$-amino nitrogen (24 \pm $2 \%)$ was observed among all the IMFs $(p>0.05)$, while the $\mathrm{DH}$ varied among IMFs (from 35 to 61\%) (Fig. 4). This means that most of the peptide bond cleavages resulted in the release of amino acids for the unheated IMFs and the heated control IMFs $(\mathrm{DH}=35-40 \%)$. In contrast, the heated $\mathrm{LF}^{+} \alpha-\mathrm{LA}^{+}$IMFs after digestion also contained a significant amount of small peptides $(\mathrm{DH}=61 \%)$. The higher proportion of peptides generated for the heated $\mathrm{LF}^{+} \alpha-\mathrm{LA}^{+}$IMFs could be due to the products of LF hydrolysis during the gastric digestion, resistant to intestinal digestion (Fig. 2A.II).

The bioaccessibility of the essential amino acids was approximatively 3-times higher than that of the non-essential amino acids ( $36 \pm 2 \%$ and $11 \pm 1 \%$, respectively). These values were much lower than the true amino acid digestibility (superior to $85 \%$ ) of bovine milk-based IMFs as determined in animal models. ${ }^{59,60}$ This can be explained by the lack of brush borders peptidases in the present in vitro digestion model, enzymes which drive the final stages of hydrolysis into amino acids. ${ }^{61,62}$ The bioaccessibility of lysine, phenylalanine, tyrosine, leucine ( $59 \pm 3 \% ; 57 \pm 3 \% ; 59 \pm 5 \% ; 40 \pm 2 \%$, respectively) and arginine $(81 \pm 10 \%)$ were higher than those of the other amino acids at the end of in vitro digestion for all IMFs (Fig. 5B). These results agreed with the cleavage specificities 


\begin{tabular}{|c|c|c|c|c|c|c|c|c|}
\hline \multirow[b]{2}{*}{$\begin{array}{l}\text { Amino acid } \\
\text { category }\end{array}$} & \multicolumn{6}{|c|}{ Bioaccessibility (\%) } & \multicolumn{2}{|r|}{ Effect of } \\
\hline & $\begin{array}{c}\text { Control } \\
\text { Unheated }\end{array}$ & $\begin{array}{l}\text { Control } \\
\text { Heated at } \\
67.5^{\circ} \mathrm{C}\end{array}$ & $\begin{array}{l}\text { Control } \\
\text { Heated at } \\
80^{\circ} \mathrm{C}\end{array}$ & $\begin{array}{l}\mathrm{LF}^{+} \alpha-\mathrm{LA}^{+} \\
\text {Unheated }\end{array}$ & $\begin{array}{c}\mathrm{LF}^{+} \alpha-\mathrm{LA}^{+} \\
\text {Heated at } \\
67.5^{\circ} \mathrm{C}\end{array}$ & $\begin{array}{c}\mathrm{LF}^{+} \alpha-\mathrm{LA}^{+} \\
\text {Heated at } \\
80^{\circ} \mathrm{C}\end{array}$ & Formula & Formula/Treatment \\
\hline Essential & $34.1 \pm 1.5^{\mathrm{ab}}$ & $36.2 \pm 3.1^{\mathrm{ab}}$ & $35.5 \pm 1.2^{\mathrm{ab}}$ & $32.6 \pm 0.9^{b}$ & $37.7 \pm 2.0^{\mathrm{a}}$ & $36.9 \pm 0.8^{\mathrm{ab}}$ & NS & * \\
\hline Non-essential & $10.2 \pm 0.7$ & $10.8 \pm 2.0$ & $10.3 \pm 0.6$ & $11.0 \pm 1.8$ & $13.2 \pm 0.8$ & $12.6 \pm 0.6$ & $* *$ & NS \\
\hline
\end{tabular}

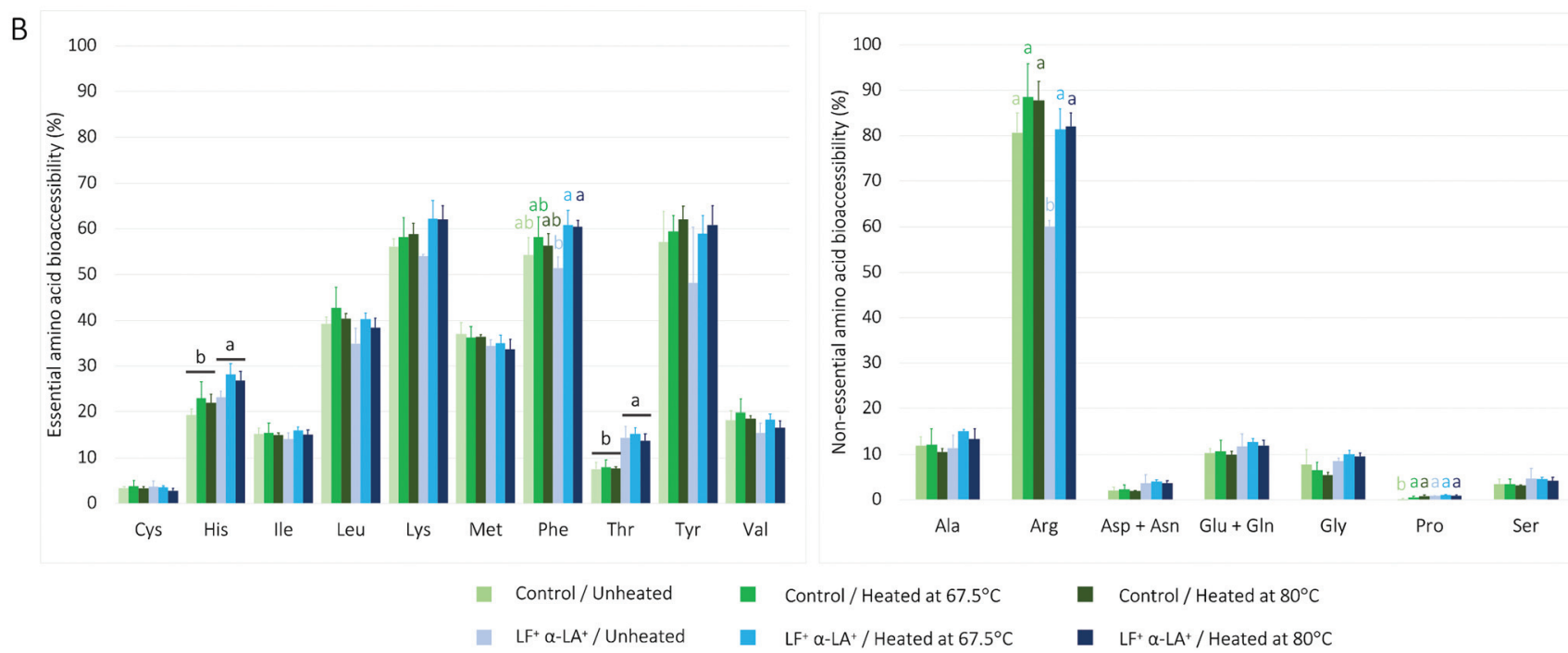

Fig. 5 Bioaccessibility of total (A) and individual (B) essential and non-essential amino acids released at the end of the in vitro intestinal digestion of the unheated and heated control and $\mathrm{LF}^{+} \alpha-\mathrm{LA}^{+}$IMFs. (A) The (non-) essential amino acid bioaccessibility was expressed as the ratio of the sum of free (non-)essential amino acid contents in digesta ( $\mathrm{g} \mathrm{kg}^{-1}$ of IMF) related to the sum of total (non-) essential amino acid contents within IMFs ( $\mathrm{g}$ $\mathrm{kg}^{-1}$ of IMF). The essential amino acids were cysteine, histidine, isoleucine, leucine, lysine, methionine, phenylalanine, threonine, tyrosine and valine. The non-essential amino acids were alanine, arginine, aspartic acid, asparagine, glutamic acid, glutamine, glycine, proline and serine. Statistically significant factors were referenced with $p<0.001\left(^{(* *)}, p<0.01\left(^{* *}\right), p<0.05(*)\right.$ and $p>0.05$ (NS). (B) Data represent means \pm SD ( $n=3$ ). Different superscript letters for a given amino acid represent significant difference $(p<0.05)$.

for pepsin (phenylalanine, tyrosine, leucine and tryptophan residues) ${ }^{63}$ and trypsin (arginine and lysine residues) ${ }^{64}$ endopeptidases, in addition to the action of the carboxypeptidase contained in pancreatin (exopeptidase). For all IMFs, a very low amount of proline was released at the end of intestinal digestion, mostly due to the absence of aminopeptidases in the present in vitro digestion model. ${ }^{65}$

\section{Conclusion}

The present study underlined the impacts of protein structures within IMFs, resulting from variation of whey protein profile and heating conditions, on the protein digestion kinetics under simulated in vitro static term infant digestion.

Gastric aggregation of caseins was strongly influenced by the casein micelle structures within IMFs. The casein micelles within the unheated control IMF (i.e. native micelles) led to the formation of larger curd particles $(\sim 100 \mu \mathrm{m})$ compared to those contained in the heated IMFs (i.e. micelles covered by denatured whey proteins) $(\sim 10 \mu \mathrm{m})$ or in the unheated $\mathrm{LF}^{+}$
$\alpha$-LA ${ }^{+}$IMF (i.e. dissociated micelles) $(\sim 1 \mu \mathrm{m})$. As a consequence, caseins in the larger curd particles were found to be less susceptible to pepsin hydrolysis due to the limited access to cleavage sites.

The resistance of $\alpha$-LA and $\beta$-LG to pepsin hydrolysis was unchanged by the heating of IMFs. On the contrary, the heating of IMFs drastically decreased the resistance of LF to pepsin hydrolysis compared to the compact globular native form. Thus, the kinetics of hydrolysis during the whole intestinal digestion was enhanced for the IMFs containing denatured LF compared to the other IMFs. The hydrolysis of denatured LF could be balanced by some remaining bioactive properties (iron-binding properties, antimicrobial and antifungal activities) of generated peptides. However, other functionalities of native LF are likely to be altered (e.g. anti-inflammatory activity), which remains to be explored in vivo. Meanwhile, alternative treatments to intense heating, such as low-heat or non-thermal treatments, could be considered to guarantee the nutritional benefits of the IMF supplementation with LF. Finally, the dynamic aspect of the digestion could modulate the present results and this aspect will be con- 
sidered by using an in vitro dynamic digestion model in a future study.

\section{Conflicts of interest}

There are no conflicts of interest to declare.

\section{Acknowledgements}

We would like to thank Ingredia Dairy Experts and Agropur Inc in providing LF and $\alpha$-LA powders used for the study. We would also like to thank G. Henry, O. Ménard and J. Ossemond for the technical support. This work was supported by the Brittany Region, France (Grant ARED 17-032) and the Institut National de Recherche pour l'Agriculture, l'Alimentation et l'Environnement (INRAE, France).

\section{References}

1 R. Floris, T. Lambers, A. Alting and J. Kiers, Trends in Infant Formulas: A Dairy Perspective, in Improving the Safety and Quality of Milk, 2010, vol. 2, pp. 454-474.

2 D. K. Thompkinson and S. Kharb, Aspects of Infant Food Formulation, Compr. Rev. Food Sci. Food Saf., 2007, 6(4), 79-102.

3 D. E. W. Chatterton, D. N. Nguyen, S. B. Bering and P. T. Sangild, Anti-Inflammatory Mechanisms of Bioactive Milk Proteins in the Intestine of Newborns, Int. J. Biochem. Cell Biol., 2013, 45(8), 1730-1747, DOI: 10.1016/j. biocel.2013.04.028.

4 W. E. Heine, P. D. Klein and P. J. Reeds, The Importance of $\alpha$-Lactalbumin in Infant Nutrition, J. Nutr., 1991, 121(3), 277-283, DOI: 10.1093/jn/121.3.277.

5 M. W. Yogman, S. H. Zeisel and C. Roberts, Assessing Effects of Serotonin Precursors on Newborn Behavior, J. Psychiatr. Res., 1982, 17(2), 123-133, DOI: 10.1016/00223956(82)90014-0.

6 S. Rudloff and C. Kunz, Protein and Nonprotein Nitrogen Components in Human Milk, Bovine Milk, and Infant Formula: Quantitative and Qualitative Aspects in Infant Nutrition, J. Pediatr. Gastroenterol. Nutr., 1997, 24(3), 328344, DOI: 10.1097/00005176-199703000-00017.

7 A. Fazzolari-Nesci, D. Domianello, V. Sotera and N. Räihä, Tryptophan Fortification of Adapted Formula Increases Plasma Tryptophan Concentrations to Levels Not Different from Those Found in Breast-Fed Infants, J. Pediatr. Gastroenterol. Nutr., 1992, 14(4), 456-459, DOI: 10.1097/ 00005176-199205000-00014.

8 R. M. Hanning, B. Paes and S. A. Atkinson, Protein Metabolism and Growth of Term Infants in Response to a Reduced-Protein, 40 : 60 Whey: Casein Formula with Added Tryptophan, Am. J. Clin. Nutr., 1992, 56(6), 1004-1011, DOI: 10.1093/ajen/56.6.1004.
9 M. Totzauer, V. Luque, J. Escribano, R. Closa-Monasterolo, E. Verduci, A. ReDionigi, J. Hoyos, J.-P. Langhendries, D. Gruszfeld, P. Socha, B. Koletzko, V. Grote and for The European Childhood Obesity Trial Study Group, Effect of Lower Versus Higher Protein Content in Infant Formula Through the First Year on Body Composition from 1 to 6 Years: Follow-Up of a Randomized Clinical Trial, Obesity, 2018, 26(7), 1203-1210, DOI: 10.1002/oby.22203.

10 M. A. Fenelon, R. M. Hickey, A. Buggy, N. McCarthy and E. G. Murphy, Chapter 12 - Whey Proteins in Infant Formula, in Whey Proteins, ed. H. C. Deeth and N. Bansal, 2019, pp. 439-494.

11 A. Pierce, D. Colavizza, M. Benaissa, P. Maes, A. Tartar, J. Montreuil and G. Spik, Molecular Cloning and Sequence Analysis of Bovine Lactotransferrin, Eur. J. Biochem., 1991, 196(1), 177-184, DOI: 10.1111/j.1432-1033.1991.tb15801.x.

12 O. Sandström, B. Lönnerdal, G. Graverholt and O. Hernell, Effects of $\alpha$-Lactalbumin-Enriched Formula Containing Different Concentrations of Glycomacropeptide on Infant Nutrition, Am. J. Clin. Nutr., 2008, 87(4), 921-928.

13 A. M. Davis, B. J. Harris, E. L. Lien, K. Pramuk and J. Trabulsi, $\alpha$-Lactalbumin-Rich Infant Formula Fed to Healthy Term Infants in a Multicenter Study: Plasma Essential Amino Acids and Gastrointestinal Tolerance, Eur. J. Clin. Nutr., 2008, 62(11), 1294-1301.

14 J. C. King, G. E. Cummings, N. Guo, L. Trivedi, B. X. Readmond, V. Keane, S. Feigelman and R. de Waard, A Double-Blind, Placebo-Controlled, Pilot Study of Bovine Lactoferrin Supplementation in Bottle-Fed Infants, J. Pediatr. Gastroenterol. Nutr., 2007, 44(2), 245-251.

15 H. E. Zenker, G. A. A. van Lieshout, M. P. van Gool, M. C. E. Bragt and K. A. Hettinga, Lysine Blockage of Milk Proteins in Infant Formula Impairs Overall Protein Digestibility and Peptide Release, Food Funct., 2020, 11(1), 358-369, DOI: 10.1039/C9FO02097G.

16 L. Sánchez, J. M. Peiró, H. Castillo, M. D. Pérez, J. M. Ena and M. Calvo, Kinetic Parameters for Denaturation of Bovine Milk Lactoferrin, J. Food Sci., 1992, 57(4), 873-879, DOI: 10.1111/j.1365-2621.1992.tb14313.x.

17 Y. Wada and B. Lönnerdal, Effects of Different Industrial Heating Processes of Milk on Site-Specific Protein Modifications and Their Relationship to in Vitro and in Vivo Digestibility, J. Agric. Food Chem., 2014, 62(18), 41754185, DOI: 10.1021/jf501617s.

18 M. Lacroix, J. Léonil, C. Bos, G. Henry, G. Airinei, J. Fauquant, D. Tomé and C. Gaudichon, Heat Markers and Quality Indexes of Industrially Heat-Treated [15N] Milk Protein Measured in Rats, J. Agric. Food Chem., 2006, 54(4), 1508-1517, DOI: 10.1021/jf051304d.

19 D. Dupont, G. Mandalari, D. Mollé, J. Jardin, O. RoletRépécaud, G. Duboz, J. Léonil, C. E. N. Mills and A. R. Mackie, Food Processing Increases Casein Resistance to Simulated Infant Digestion, Mol. Nutr. Food Res., 2010, 54(11), 1677-1689, DOI: 10.1002/mnfr.200900582.

20 E. Leeb, A. Götz, T. Letzel, S. C. Cheison and U. Kulozik, Influence of Denaturation and Aggregation of 
$\beta$-Lactoglobulin on Its Tryptic Hydrolysis and the Release of Functional Peptides, Food Chem., 2015, 187, 545-554, DOI: 10.1016/j.foodchem.2015.04.034.

21 S. Zhang and B. Vardhanabhuti, Effect of Initial Protein Concentration and $\mathrm{PH}$ on in Vitro Gastric Digestion of Heated Whey Proteins, Food Chem., 2014, 145, 473-480, DOI: 10.1016/j.foodchem.2013.08.076.

22 A. Halabi, A. Deglaire, M. Hennetier, F. Violleau, A. Burel, S. Bouhallab, D. Dupont and T. Croguennec, Structural Characterization of Heat-Induced Protein Aggregates in Model Infant Milk Formulas, Food Hydrocolloids, 2020, 105928, DOI: 10.1016/j.foodhyd.2020.105928.

23 A. Brodkorb, L. Egger, M. Alminger, P. Alvito, R. Assunção, S. Ballance, T. Bohn, C. Bourlieu-Lacanal, R. Boutrou, F. Carrière, A. Clemente, M. Corredig, D. Dupont, C. Dufour, C. Edwards, M. Golding, S. Karakaya, B. Kirkhus, S. Le Feunteun, U. Lesmes, A. Macierzanka, A. R. Mackie, C. Martins, S. Marze, D. J. McClements, O. Ménard, M. Minekus, R. Portmann, C. N. Santos, I. Souchon, R. P. Singh, G. E. Vegarud, M. S. J. Wickham, W. Weitschies and I. Recio, INFOGEST Static in Vitro Simulation of Gastrointestinal Food Digestion, Nat. Protoc., 2019, 14(4), 991-1014, DOI: 10.1038/s41596-018-0119-1.

24 O. Ménard, C. Bourlieu, S. C. De Oliveira, N. Dellarosa, L. Laghi, F. Carrière, F. Capozzi, D. Dupont and A. Deglaire, A First Step towards a Consensus Static in Vitro Model for Simulating Full-Term Infant Digestion, Food Chem., 2018, 240, 338-345, DOI: 10.1016/j. foodchem.2017.07.145.

25 A.-I. Mulet-Cabero, A. R. Mackie, P. J. Wilde, M. A. Fenelon and A. Brodkorb, Structural Mechanism and Kinetics of in Vitro Gastric Digestion Are Affected by Process-Induced Changes in Bovine Milk, Food Hydrocolloids, 2019, 86, 172183, DOI: 10.1016/j.foodhyd.2018.03.035.

26 F. C. Church, H. E. Swaisgood, D. H. Porter and G. L. Catignani, Spectrophotometric Assay Using O-Phthaldialdehyde for Determination of Proteolysis in Milk and Isolated Milk Proteins, J. Dairy Sci., 1983, 66(6), 1219-1227.

27 M. G. Davies and A. J. Thomas, An Investigation of Hydrolytic Techniques for the Amino Acid Analysis of Foodstuffs, J. Sci. Food Agric., 1973, 24(12), 1525-1540, DOI: 10.1002/jsfa.2740241208.

28 S. Moore, D. Spackman and W. Stein, Chromatography of Amino Acids on Sulfonated Polystyrene Resins, Anal. Chem., 1958, 1186-1190.

29 P. Fox, T. Uniacke-Lowe, P. McSweeney and J. O'Mahony, Milk Proteins, in Dairy Chemistry and Biochemistry, 2015.

30 J. Castellino, W. Fish and G. Kenneth, Studies on Bovine Lactoferrin, J. Biol. Chem., 1970, 245(17), 4269-4275.

31 A. Mondino, G. Bongiovanni, S. Fumero and L. Rossi, An Improved Method of Plasma Deproteination with Sulphosalicylic Acid for Determining Amino Acids and Related Compounds, J. Chromatogr. A, 1972, 74(2), 255-263.

32 S. H. C. Lin, S. L. Leong, R. K. Dewan, V. A. Bloomfield and C. V. Morr, Effect of Calcium Ion on the Structure of Native
Bovine Casein Micelles, Biochemistry, 1972, 11(10), 18181821, DOI: 10.1021/bi00760a013.

33 A. Ye, J. Cui, D. Dalgleish and H. Singh, Formation of a Structured Clot during the Gastric Digestion of Milk: Impact on the Rate of Protein Hydrolysis, Food Hydrocolloids, 2016, 52, 478-486, DOI: 10.1016/j. foodhyd.2015.07.023.

34 L. Donato, M. Alexander and D. G. Dalgleish, Acid Gelation in Heated and Unheated Milks: Interactions between Serum Protein Complexes and the Surfaces of Casein Micelles, J. Agric. Food Chem., 2007, 55(10), 4160-4168, DOI: $10.1021 /$ jf063242c.

35 G. Martin, R. Williams and D. Dunstan, Comparison of Casein Micelles in Raw and Reconstituted Skim Milk, J. Dairy Sci., 2007, 90, 4543-4551, DOI: 10.3168/jds.20070166.

36 J. E. Plowman and L. K. Creamer, Restrained Molecular Dynamics Study of the Interaction between Bovine $\kappa$-Casein Peptide 98-111 and Bovine Chymosin and Porcine Pepsin, J. Dairy Res., 1995, 62(3), 451-467, DOI: 10.1017/ S0022029900031150.

37 S. C. de Oliveira, A. Deglaire, O. Ménard, A. Bellanger, F. Rousseau, G. Henry, E. Dirson, F. Carrière, D. Dupont and C. Bourlieu, Holder Pasteurization Impacts the Proteolysis, Lipolysis and Disintegration of Human Milk under in Vitro Dynamic Term Newborn Digestion, Food Res. Int., 2016, 88, 263-275, DOI: 10.1016/j. foodres.2015.11.022.

38 S. G. Anema and C. G. (Kees) de Kruif, Protein Composition of Different Sized Casein Micelles in Milk after the Binding of Lactoferrin or Lysozyme, J. Agric. Food Chem., 2013, 61(29), 7142-7149, DOI: 10.1021/jf401270h.

39 S. G. Anema, Acidification of Lactoferrin-Casein Micelle Complexes in Skim Milk, Int. Dairy J., 2019, 99, 104550, DOI: 10.1016/j.idairyj.2019.104550.

40 F. Guyomarc'h, C. Queguiner, A. J. R. Law, D. S. Horne and D. G. Dalgleish, Role of the Soluble and Micelle-Bound Heat-Induced Protein Aggregates on Network Formation in Acid Skim Milk Gels, J. Agric. Food Chem., 2003, 51(26), 7743-7750, DOI: 10.1021/jf030201x.

41 A. Deglaire, S. D. Oliveira, J. Jardin, V. Briard-Bion, F. Kroell, M. Emily, O. Ménard, C. Bourlieu and D. Dupont, Impact of Human Milk Pasteurization on the Kinetics of Peptide Release during in Vitro Dynamic Digestion at the Preterm Newborn Stage, Food Chem., 2019, 281, 294-303, DOI: 10.1016/j.foodchem.2018.12.086.

42 T. P. T. Nguyen, Digestibility and Structural Changes of Ingredients in Infant Formulae during the Gastrointestinal Digestion, 2017.

43 C. Bourlieu, O. Ménard, A. De La Chevasnerie, L. Sams, F. Rousseau, M.-N. Madec, B. Robert, A. Deglaire, S. Pezennec, S. Bouhallab, F. Carrière and D. Dupont, The Structure of Infant Formulas Impacts Their Lipolysis, Proteolysis and Disintegration during in Vitro Gastric Digestion, Food Chem., 2015, 182, 224-235, DOI: 10.1016/j. foodchem.2015.03.001. 
44 N. Kitabatake and Y.-I. Kinekawa, Digestibility of Bovine Milk Whey Protein and $\beta$-Lactoglobulin in Vitro and in Vivo, J. Agric. Food Chem., 1998, 46(12), 4917-4923, DOI: 10.1021/jf9710903.

45 E. G. P. Stender, G. Koutina, K. Almdal, T. Hassenkam, A. Mackie, R. Ipsen and B. Svensson, Isoenergic Modification of Whey Protein Structure by Denaturation and Crosslinking Using Transglutaminase, Food Funct., 2018, 9(2), 797-805, DOI: 10.1039/C7FO01451A.

46 M. R. Peram, S. M. Loveday, A. Ye and H. Singh, In Vitro Gastric Digestion of Heat-Induced Aggregates of $\beta$-Lactoglobulin, J. Dairy Sci., 2013, 96(1), 63-74, DOI: 10.3168/jds.2012-5896.

47 H. Singh and L. K. Creamer, In Vitro Digestibility of Whey Protein/K-Casein Complexes Isolated from Heated Concentrated Milk, J. Food Sci., 1993, 58(2), 299-302, DOI: 10.1111/j.1365-2621.1993.tb04260.x.

48 J. R. Britton and O. Koldovsky, Gastric Luminal Digestion of Lactoferrin and Transferrin by Preterm Infants, Early Hum. Dev., 1989, 19(2), 127-135, DOI: 10.1016/0378-3782 (89)90123-0.

49 N. Stănciuc, I. Aprodu, G. Râpeanu, I. van der Plancken, G. Bahrim and M. Hendrickx, Analysis of the Thermally Induced Structural Changes of Bovine Lactoferrin, J. Agric. Food Chem., 2013, 61(9), 2234-2243, DOI: 10.1021/ jf305178s.

50 A. M. Moscovici, Y. Joubran, V. Briard-Bion, A. Mackie, D. Dupont and U. Lesmes, The Impact of the Maillard Reaction on the in Vitro Proteolytic Breakdown of Bovine Lactoferrin in Adults and Infants, Food Funct., 2014, 5(8), 1898-1908, DOI: 10.1039/C4FO00248B.

51 S. Sharma, M. Sinha, S. Kaushik, P. Kaur and T. P. Singh, C-Lobe, of Lactoferrin: The Whole Story of the HalfMolecule, Biochem. Res. Int., 2013, 2013, 1-8, DOI: 10.1155/ 2013/271641.

52 N. Rastogi, A. Singh, S. N. Pandey, M. Sinha, A. Bhushan, P. Kaur, S. Sharma and T. P. Singh, Structure of the Iron-Free True C-Terminal Half of Bovine Lactoferrin Produced by Tryptic Digestion and Its Functional Significance in the Gut, FEBS J., 2014, 281(12), 2871-2882, DOI: 10.1111/febs.12827.

53 N. Rastogi, N. Nagpal, H. Alam, S. Pandey, L. Gautam, M. Sinha, K. Shin, N. Manzoor, J. S. Virdi, P. Kaur, S. Sharma and T. P. Singh, Preparation and Antimicrobial Action of Three Tryptic Digested Functional Molecules of Bovine Lactoferrin, PLoS One, 2014, 9(3), e90011, DOI: 10.1371/journal.pone.0090011.

54 B. Lönnerdal, Human Milk: Bioactive Proteins/Peptides and Functional Properties, in Nestlé Nutrition Institute Workshop Series, ed. J. Bhatia, R. Shamir and Y. Vandenplas, S. Karger AG, 2016, vol. 86, pp. 97-107. DOI: 10.1159/000442729.
55 F. Fan, M. Liu, P. Shi, S. Xu, W. Lu and M. Du, Effects of Thermal Treatment on the Physicochemical Properties and Osteogenic Activity of Lactoferrin, J. Food Process. Preserv., 2019, 43(9), e14068, DOI: 10.1111/jfpp.14068.

56 S. Harouna, J. J. Carramiñana, F. Navarro, M. D. Pérez, M. Calvo and L. Sánchez, Antibacterial Activity of Bovine Milk Lactoferrin on the Emerging Foodborne Pathogen Cronobacter Sakazakii: Effect of Media and Heat Treatment, Food Control, 2015, 47, 520-525, DOI: 10.1016/j. foodcont.2014.07.061.

57 L. L. Roux, R. Chacon, D. Dupont, R. Jeantet, A. Deglaire and F. Nau, In Vitro Static Digestion Reveals How Plant Proteins Modulate Model Infant Formula Digestibility, Food Res. Int., 2020, 130, 108917, DOI: 10.1016/j. foodres.2019.108917.

58 A. Deglaire, C. Fromentin, H. Fouillet, G. Airinei, C. Gaudichon, C. Boutry, R. Benamouzig, P. J. Moughan, D. Tomé and C. Bos, Hydrolyzed Dietary Casein as Compared with the Intact Protein Reduces Postprandial Peripheral, but Not Whole-Body, Uptake of Nitrogen in Humans, Am. J. Clin. Nutr., 2009, 90(4), 1011-1022, DOI: 10.3945/ajcn.2009.27548.

59 S. M. Rutherfurd, A. J. Darragh, W. H. Hendriks, C. G. Prosser and D. Lowry, True Ileal Amino Acid Digestibility of Goat and Cow Milk Infant Formulas, J. Dairy Sci., 2006, 89(7), 2408-2413, DOI: 10.3168/jds. S0022-0302(06)72313-X.

60 G. Sarwar, R. W. Peace and H. G. Botting, Differences in Protein Digestibility and Quality of Liquid Concentrate and Powder Forms of Milk-Based Infant Formulas Fed to Rats, Am. J. Clin. Nutr., 1989, 49(5), 806-813, DOI: 10.1093/ajcn/ 49.5.806.

61 G. Picariello, B. Miralles, G. Mamone, L. Sanchez-Rivera, I. Recio, F. Addeo and P. Ferranti, Role of Intestinal Brush Border Peptidases in the Simulated Digestion of Milk Proteins, Mol. Nutr. Food Res., 2015, 59(5), 948-956, DOI: 10.1002/mnfr.201400856.

62 N. Tobey, W. Heizer, R. Yeh, T.-I. Huang and C. Hoffner, Human Intestinal Brush Border Peptidases, Gastroenterology, 1985, 88(4), 913-926, DOI: 10.1016/S00165085(85)80008-1.

63 K. Inouye and J. S. Fruton, Studies on the Specificity of Pepsin *, Biochemistry, 1967, 6(6), 1765-1777, DOI: 10.1021/ bi00858a027.

64 B. Keil, Specificity of Proteolysis, Springer-Verlag BerlinHeidelberg-New York, New York, 1st edn, 1992.

65 I. L. Huërou-Luron, Chapter 16 Production and Gene Expression of Brush Border Disaccharidases and Peptidases during Development in Pigs and Calves, in Biology of Growing Animals, Elsevier, 2002, vol. 1, pp. 491-513. DOI: 10.1016/S1877-1823(09)70132-8. 